\title{
AUGMENTATION OF SURGICALLY CREATED BONY DEFECTS USING BIPHASIC CALCIUM PHOSPHATE WITH AND WITHOUT PLATELET RICH FIBRIN: AN EXPERIMENTAL STUDY IN SHEEP
}

\author{
AlKafarani W. M. ${ }^{*}$ and BabAn L. F. \\ *Dept. of oral and maxillofacial Surgery and Periodontics, College of dentistry, University of Duhok, \\ Kurdistan Region- Iraq. \\ *** Dept. of Oral and Maxillofacial Surgery, College of Dentistry, Hawler Medical University, \\ Kurdistan Region-Iraq.
}

(Received: November 10, 2019; Accepted for Publication: December 24, 2019)

\begin{abstract}
Back ground and objective: The reconstruction of large bony defects is one of great challenge in clinical research, various materials and techniques were used in bone augmentation. Recently, autologous platelet rich fibrin (PRF) which contain various growth factors accelerates tissue healing and promotes bone regeneration. Therefore, this study aimed to evaluate the effectiveness of adding PRF to biphasic calcium phosphate (BCP) on healing process of iliac bone defects in sheep.

Materials and methods: six iliac bone defect $8 \mathrm{~mm}$ in diameters and depth were created in each side of four sheep. The superior two defects were filled with blood as control group, the middle two defects were filled with BCP and the inferior two defects were filled with a mixture of BCP and PRF equally. The PRF was prepared by centrifuging sheep own blood at 2700rpm for 12minutes. One sheep was sacrificed at 2 , 4, 6 and 12 postoperatively weeks, and twelve iliac bone block from each period were prepared histologically and the slides stained with masson trichrome, hematoxylin and eosin stains for examination of new bone formation, bone maturation and intensity of osteoblast and osteoclast over healing time periods.

Results: The study showed that the new bone formation percentage and the intensity of osteoblast and osteoclast cells were significantly increased in each group with healing time $(p=\langle 0.05)$ and they were in BCP+PRF group was higher than in BCP group and much higher than in control group at all-time intervals. Besides, the woven and lamellar bone percentages over time periods were significantly decreased and increased, respectively. Importantly, the study revealed that the (BCP+PRF) group had statistically significant increase in the percentage of new bone formation and lamellar bone and compared to the BCP and control groups in all time intervals.

Conclusion: Within the limitations of this experimental study, our results demonstrated that the addition of PRF to BCP increases the formation of new bone.
\end{abstract}

KEY WORDS: Platelet Rich Fibrin, Biphasic Calcium Phosphate, Bone Augmentation, Bone Healing. Abbreviation: (BCP) biphasic calcium phosphate.

(PRF) platelet rich fibrin.

\section{INTRODUCTION}

$\mathbf{T}$ The augmentation of large bone defects resulting from trauma, infection, tumor and surgical resection remains a great challenge in clinical and medical research (Chen et al., 2017). Different bone graft materials have been developed and used for reconstruction of osseous defects in oral and maxillofacial surgeries (Lee et al., 2015). The autogenous bone graft is considered as the gold standard for bone reconstruction because of its histocompatibility, osteoinductivity and osteogenesity (Kumar et al., 2013). However, it has some clinical limitations in terms of availability, uncontrolled resorption rate, morbidity and pain in donor site, in case of allograft and xenograft the disadvantages are possibility of immunological reaction, risk of disease transmission and loss of biological properties due to sterilization process, to overcome these drawbacks many attempts have been develop to obtain synthetic bone substitutes which is osteoconductive and act as scaffold for 
new bone and blood vessels formation (Kim et al., 2017)

Among various synthetic bone substitute biphasic calcium phosphate (BCP) have been widely used because of their chemical and structural similarity to human bone and it composed of less soluble hydroxyapatite (HA) to provide space maintenance and more biodegradable $\beta$-tricalcium phosphate $(\beta$-TCP) to control resorption rate. It is a biocompatible, osteoconductive, and cost-effective biomaterial (Bölükbaş1 et al., 2013), but its osteoinductive potential is poor (Kim et al., 2017); therefore different bioactive material rich in growth factors widely being used either alone or together with bone graft substances for bone augmentation and regeneration particularly in maxillofacial surgery. Among these factors are platelet-rich plasma (PRP) and platelet-rich fibrin (PRF) (Abdullah, 2016)

PRF was first developed in France by Choukroun in 2001 as an autologous healing biomaterial that contains leukocyte, platelets and growth factors (Choukroun et al., 2001), PRF used specifically in oral and maxillofacial surgery and considered to be a new generation of platelet concentrate currently (Borie et al., 2015). PRF has advantages over PRP by having a strong fibrin structure and not requiring any biochemical modification through bovine thrombin or anticoagulants (Öncü et al., 2016) and has a very significant slow sustained release of key growth factors for at least 1 week and up to 28 days (Agrawal, 2017)

PRF is prepared by a centrifugation through slowly progressive polymerization process, which increases integration of the circulating cytokines and growth factors in the fibrin mesh and prevents them from undergoing proteolysis and prolong promotion of tissue growth (Rady et al., 2018). PRF has been used in different procedures of oral and maxillofacial surgery such as socket preservation, sinus lift and bone augmentation, root coverage procedures, and healing in donor site with good results (Cortese et al., 2016)

PRF is a second generation of platelet concentrate in an autologous fibrin matrix contain a variety of active growth factors and leukocyte cytokines, including the transforming growth factor(TGF), platelet-derived growth factor (PDGF), vascular endothelial growth factor(VEGF), insulin-like growth factor (IGF), epidermal growth factor (EGF), interleukin 1(IL 1) and interleukin 6(IL 6).These growth factors and interleukins play a key role in hemostasis and wound healing and accelerate bone regeneration by angiogenesis, osteoblastic proliferation and differentiation which makes PRF advantageous and more reliable for bone healing (Kökdere et al., 2015a)

This study aimed to evaluate the efficacy of adding PRF to biphasic calcium phosphate (BCP) on histological healing process of iliac bone defects in sheep.

\section{MATERIALS AND METHODS \\ Animal model}

The study was approved by the animal ethical committee of Dohuk Research Center (DRC) at college of veterinary medicine/University of Dohuk. All procedures were conducted in accordance with the Dohuk University ethical guidelines for the treatment and welfare of experimental animals, at Veterinary theater. The study included four adult local breed male sheep (rams) at the age of (1.5-2) years and their weight ranged from $(25-30) \mathrm{kg}$. The rams were housed indoors two weeks before surgery and subjected to a thorough clinical examination to ascertain their health status. All animals were healthy with no systemic diseases. The sheep were randomly classified into four groups, one for each. The animals were fasted for 24 hours preoperatively. The procaine penicillin and Streptomycin sulfate combination in a dose of $24 \mathrm{mg} / \mathrm{kg}$ and $30 \mathrm{mg} / \mathrm{kg}$ respectively was used 1 hour before surgery and the skin of surgical area was prepared aseptically by clipping, shaving and application of povidone-iodine.

\section{Anesthesia}

Surgical procedures were performed under general anesthesia under sterile conditions. Atropine sulfate was given intramuscularly in a dose of $1 \mathrm{mg} / 25 \mathrm{~kg}$ body weight 10 minutes before induction of the anesthesia to decreases fluid secretions, suppresses vagal tone to the heart and prevent bradycardia, then general anesthesia was induced and maintained by repeated intramuscular injection of $0.1 \mathrm{mg} / \mathrm{kg}$ of xylazine and $8 \mathrm{mg} / \mathrm{kg}$ of ketamine. Lidocaine $2 \%$ used locally to reduce the bleeding and for regional anesthesia.

\section{Surgical procedure}

After anesthesia was achieved skin, subcutaneous tissues and muscles were incised 
and dissected then the periosteum was incised and reflected to expose the ilium bone. Six defects $8 \mathrm{~mm}$ in diameter and depth in each ilium were prepared with a trephine burr $8 \mathrm{~mm}$ diameter under copious saline solution irrigation at $1500 \mathrm{rpm}$. A distance of $5 \mathrm{~mm}$ approximately was left between each defect [figure 1A]. The superior two defects were left as a control which filled with blood and the middle two defects were grafted with BCP (Osteon II, Dentium. Co. Ltd, South Korea), Finally the inferior two defects were grafted with a mixture of $\mathrm{BCP}$ and PRF at (1:1) ratio on each side of iliac bone [figure 1B]. Adequate hemostasis was obtained, then the periosteum repositioned and closed with resorpable suture, the surgical wound was closed by suture.

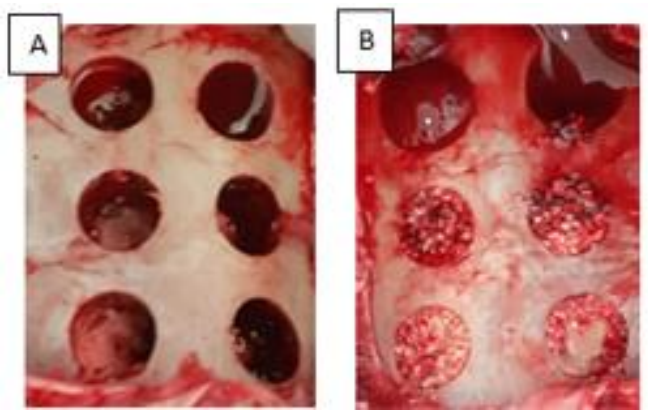

Fig. (1): (A) prepared six iliac bone defects, (B) superior 2 defects filled with blood, middle 2 defects filled with $\mathrm{BCP}$ and inferior 2 defects filled with a mixture of $\mathrm{BCP}+\mathrm{PRF}$.

\section{Postoperative care}

The animals were examined daily until removal of skin suture at the 10th postoperative day. Penicillin and streptomycin combination was continued for four successive postoperative days. The wound was sprayed daily with Oxytetracycline HCL (Limoxin -25 spray, interchemie, Holland) to cover the wound and prevent local infection. One sheep was sacrificed at 2, 4, 6 and 12 weeks. The iliac bone was carefully separated from soft tissue then cut into blocks to prepare for histological examination.

\section{PRF preparation}

A $20 \mathrm{ml}$ of venous blood was drawn rapidly after anesthesia achievement from the jugular vein into $10-\mathrm{mL}$ glass tubes without anticoagulant and the tubes immediately centrifuged for 12 minutes at $2700 \mathrm{rpm}$ (Hittech, Zentrifugen, Germany). After centrifugation, three layers were obtained: red blood cells (RBC) at the bottom, a cellular plasma at the top as platelet poor plasma (PPP) and PRF between the two layers. The PPP was collected by syringe and discarded, then the PRF clots and red corpuscles were removed from tube and separated from each other by tweezers, PRF was leaved 10 minutes approximately to allow the serum concentration release then minced into small pieces to mixed wiith $\mathrm{BCP}$ [figure 2]. 


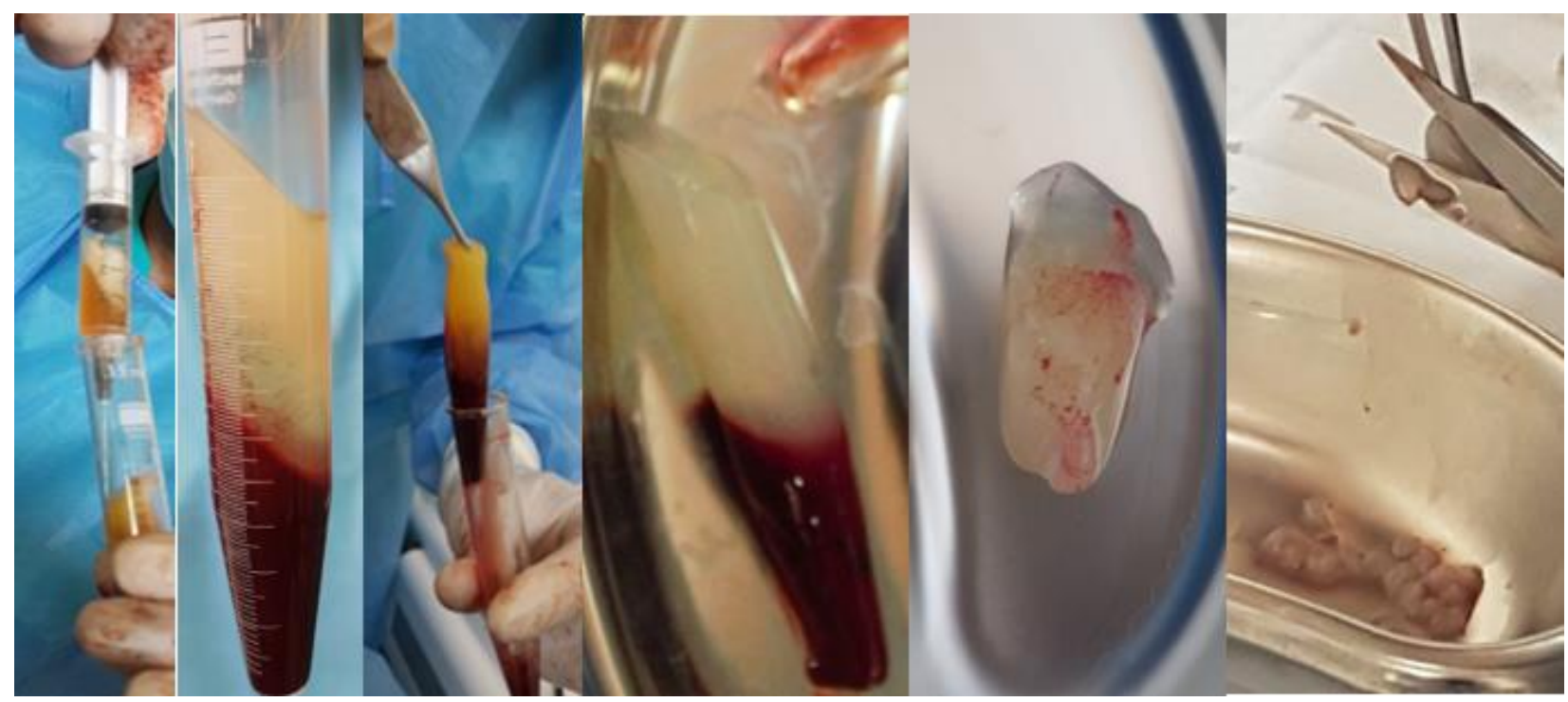

Fig. (2): steps of PRF separation from PRP and red blood cells.

\section{Histologic examination}

Each specimen was fixed in $10 \%$ buffered formalin for 48 hours. After fixation, each sample was sectioned into $2-5 \mathrm{~mm}$ thickness. The cutting lines were through the larger diameter of the defect and perpendicular to iliac bone, then the samples were treated with $5 \%$ nitric acid based solution 5 days for decalcification and routine tissue processing performed, the specimens were embedded in paraffin and sectioned into $5-\mu \mathrm{m}$ (micro millimeters) thick sections on charged slides using a microtome (Thermo scientific, HM 325 Manual microtom, United Kingdom). Finally, hematoxylin and eosin (H\&E) and Masson trichrome stains were performed. The sections were scanned by slide scanner (3D HISTIC. Ltd, Hungary) and examined with a panoramic viewer program version 1.15.4 software from (3D HISTICH. Ltd, Hungary) on computer and the histologic images were captured at $10 \times$ magnification.

At four different periods $(2,4,6$ and 12 weeks) histological study were performed, where the percentage of osteoid (newly formed bone), proportion of woven to lamellar bone, and number of osteoblast and osteoclast cells were measured. The percentage of new bone formation was determined and converted to a percentage of total area of bone defect which is $8 \mathrm{~mm}^{2}$ in this study (Jang et al., 2008) (Wang et al., 2017) and intensity or numbers of osteoblast and osteoclast were measured according to the following scores:

0 absent
1 present at periphery

2 present at center

3 present at center and

periphery(Lucaciu et al., 2015)

\section{Statistical Methods}

The descriptive purposes of the study were presented in mean and standard deviation (SD). The significant level in each group over time period was examined in one-sample t-test. The comparison of intensity of the clinical parameters of each time period among 3 groups was examined in One-way ANOVA and Bonferroni correction tests. The significant level was determined in a P-value of less than 0.05. The statistical calculations were performed by Statistical Package for Social Sciences 24 (SPSS 24; IBM Corp; USA).

\section{RESULTS}

All four sheep showed an uneventful recovery from the anesthesia and surgical procedures, they survived well, and remained active and alert all over the experiment period. There were showed an uneventful healing and no signs of infection, necrosis, hematoma, or wound dehiscence during the wound healing period. All 48 standardized iliac bone defects were included in the final analysis.

\section{Bone formation}

Table 1 display the percentage of osteoid (newly formed bone) per $8 \mathrm{~mm}^{2}$ defect which was highly significant increased with healing time in each group especially at 2,4 and 6 weeks with little 
increasing at 12 weeks and reduced at $\mathrm{BCP}$ group in 12 weeks. Besides, osteoid at each healing time point was significantly different between groups where the osteoid in $\mathrm{BCP}+\mathrm{PRF}$ group was more than in BCP group and much more than in control group at all-time intervals

[figure 3 and 4 .

Table (1): percentage of osteoid/ $8 \mathrm{~mm}^{2}$ defect of 3 groups over time periods

\begin{tabular}{|c|c|c|c|c|c|c|}
\hline \multicolumn{7}{|c|}{ Case summaries } \\
\hline \multicolumn{7}{|c|}{ Osteoid\%/defect $8 \mathrm{~mm}^{2}$} \\
\hline \multirow[t]{2}{*}{ Groups } & \multicolumn{6}{|c|}{ Healing time Period } \\
\hline & 2 wks. & 4 wks. & 6 wks. & 12 wks. & Total & P-Value \\
\hline Control & $10.00(4.08)$ & $25.00(4.08)$ & $47.50(2.89)$ & $\begin{array}{l}48.75 \\
(2.50) \\
\end{array}$ & $32.81(17.03)$ & $<0.001$ \\
\hline $\mathrm{BCP}$ & $23.75(4.79)$ & $50.00(4.08)$ & $63.75(4.79)$ & $\begin{array}{l}52.50 \\
(15.81) \\
\end{array}$ & $47.50(15.81)$ & $<0.001$ \\
\hline $\mathrm{BCP}+\mathrm{PRF}$ & $48.75(2.50)$ & $67.50(6.46)$ & $81.25(2.50)$ & $\begin{array}{r}82.50 \\
(2.89) \\
\end{array}$ & $\begin{array}{l}70.00 \\
(14.49)\end{array}$ & $<0.001$ \\
\hline P-value & $<0.001$ & $<0.001$ & $<0.001$ & $<0.001$ & & \\
\hline
\end{tabular}

Bonferroni correction tests was used for pairwise comparisons between groups at each healing time period table 2 . At all-time intervals, the lowest percentage of osteoid was observed in control group, which was mean difference $\mathrm{Z}$ and $\mathrm{P}$ - value highly significantly less than in the $\mathrm{BCP}$ at 2,4 and 6 weeks $[Z=-38.750, P=$ $<0.001, \mathrm{Z}=-25.000, \mathrm{P}=<0.001$ and $\mathrm{Z}=$ -
16.250, $\mathrm{P}=<0.001$, respectively], and nonsignificantly less than $\mathrm{BCP}$ at 12 weeks $[\mathrm{Z}=$ $-3.750, P=0.755]$, while the osteoid percentage of control group was highly significant less than in BCP+PRF group at 2,4,6 and 12 weeks. Moreover, the percentage of osteoid in $\mathrm{BCP}+\mathrm{PRF}$ was highly significant more than in $\mathrm{BCP}$ group at all time intervals [figure 3 and 4].

Table (2): comparison of osteoid percentage $/ 8 \mathrm{~mm}^{2}$ defect between groups at each time period.

\begin{tabular}{|c|c|c|c|c|c|c|}
\hline \multicolumn{7}{|c|}{ Case summaries } \\
\hline \multicolumn{7}{|c|}{ Osteoid\%/ $8 \mathrm{~mm}^{2}$ defect } \\
\hline & & & \multicolumn{4}{|c|}{ Healing time periods } \\
\hline Group (I) & Group (J) & & 2 wks & 4 wks & 6 wks & 12 wks \\
\hline \multirow[t]{2}{*}{ Control } & BCP & $Z=I-J$ & -13.750 & -25.000 & -16.250 & -3.750 \\
\hline & & P-value & 0.002 & $<0.001$ & $<0.001$ & 0.755 \\
\hline \multirow[t]{2}{*}{ Control } & $\mathrm{BCP}+\mathrm{PRF}$ & $Z=I-J$ & -38.750 & -42.500 & -33.750 & -33.750 \\
\hline & & $\mathrm{P}$-value & $<0.001$ & $<0.001$ & $<0.001$ & $<0.001$ \\
\hline \multirow[t]{2}{*}{$\mathrm{BCP}$} & $\mathrm{BCP}+\mathrm{PRF}$ & $Z=I-J$ & 25.000 & -17.500 & -17.500 & -30.000 \\
\hline & & P-value & $<0.001$ & 0.002 & $<0.001$ & $<0.001$ \\
\hline
\end{tabular}



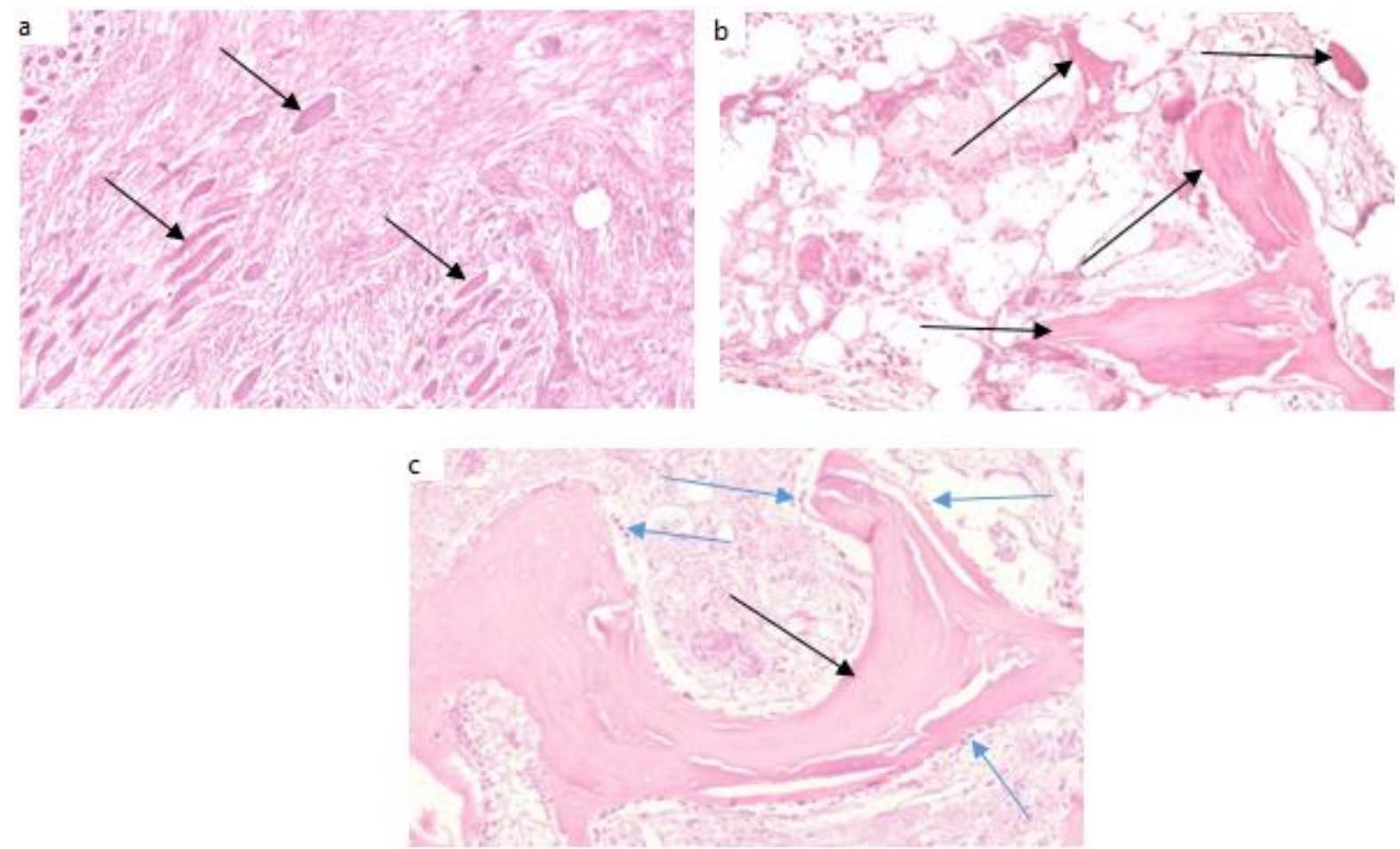

Fig. (3): Light micrograph of histology of bone defect filled with (a) blood (b) BCP and (c) BCP+PRF groups at 2 weeks postoperatively with $x 10$ magnification $(200 \mu \mathrm{m})$ show newly formed bone (black arrows) and osteoblast cell (blue arrows).
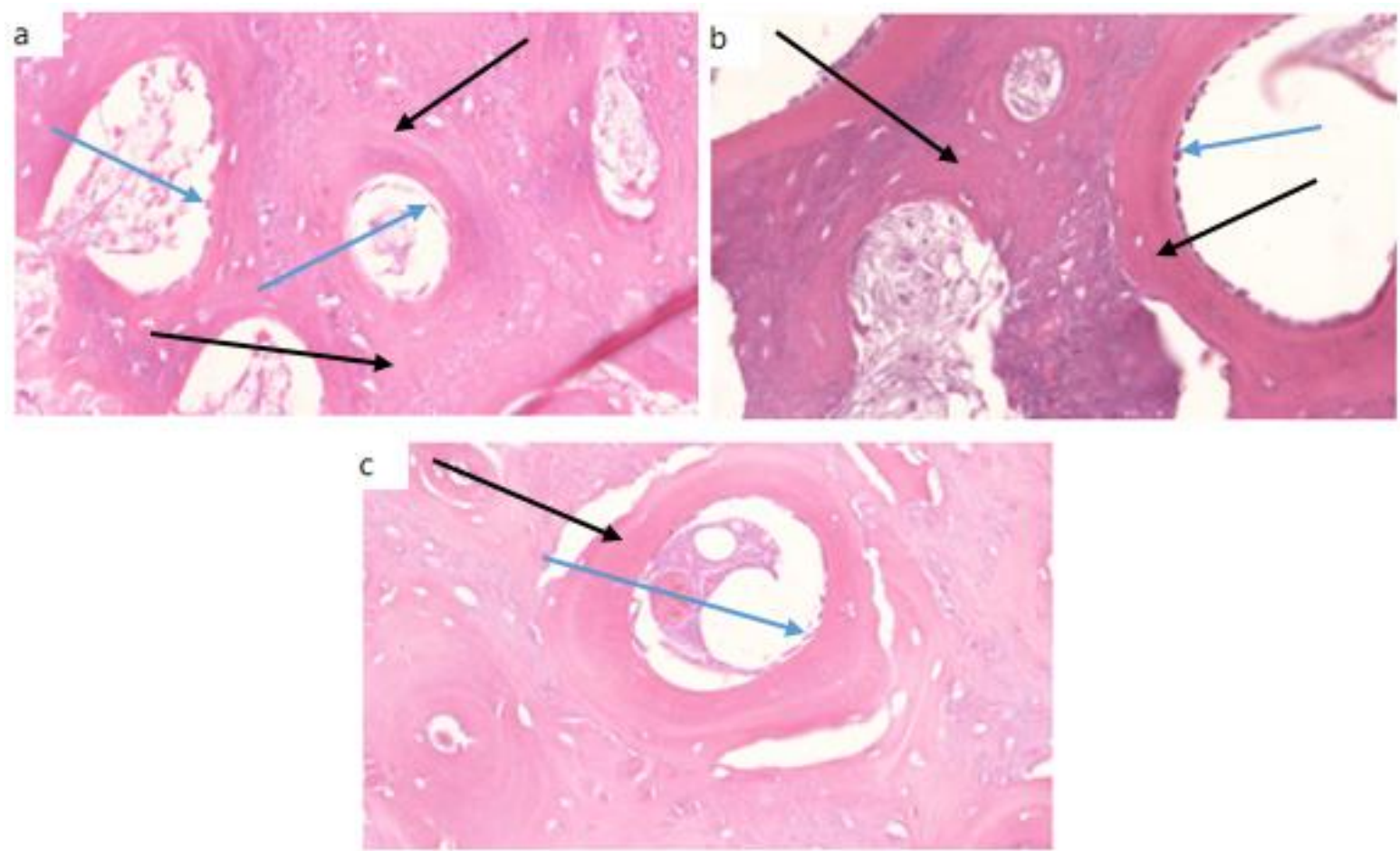

Fig. (4): light micrograph of histology of bone defect filled with (a) control, (b) BCP and (c) BCP+PRF groups at 12 weeks postoperatively with $\mathrm{x} 20$ magnification $(100 \mu \mathrm{m})$ show newly formed bone (black arrows) and osteoblast cell (blue arrows). 


\section{Maturation of bone}

Proportion of woven to lamellar bone per osteoid in $8 \mathrm{~mm}^{2}$ defect (decreased and increased, respectively) over time periods and between groups at each healing time period. Where the percentage of woven bone at all groups highly significant decreased with time and much more at 12 weeks in control and $\mathrm{BCP}$ groups while at 6 and 12 weeks in BCP+PRF group table 3 . in contrast, the lamellar bone percentage which was significantly increased with time and particularly at 12 weeks in control and BCP groups while at 6 and 12 weeks in $\mathrm{BCP}+\mathrm{PRF}$ group table 4 . That means the maturation of bone in $\mathrm{BCP}+\mathrm{PRF}$ group was faster than in control and BCP groups.

Woven and lamellar bone percentage at 2 and 4 weeks was significantly different between all groups and highly significant at 6 and 12 weeks $[0.019,0.006,<0.001,<0.001$, respectively] table 3 and 4 .

Table (3): Percentage of woven bone/osteoid of 3 groups over time periods

\begin{tabular}{|c|c|c|c|c|c|c|}
\hline \multicolumn{7}{|c|}{ Case Summaries } \\
\hline \multicolumn{7}{|c|}{ Woven\%/osteoid } \\
\hline Groups & \multicolumn{5}{|c|}{ Healing time Period } & \\
\hline & 2 wks. & 4 wks. & 6 wks. & 12 wks. & Total & P-Value \\
\hline Control & $98.75(2.500)$ & $91.25(4.787)$ & $77.50(6.455)$ & $15.00(4.082)$ & $\begin{array}{l}70.63 \\
(34.345)\end{array}$ & $<0.001$ \\
\hline $\mathrm{BCP}$ & $93.75(2.500)$ & $81.25(2.500)$ & $72.50(2.887)$ & $31.25(2.500)$ & $\begin{array}{l}69.69 \\
(24.322)\end{array}$ & $<0.001$ \\
\hline $\mathrm{BCP}+\mathrm{PRF}$ & $92.50(2.887)$ & $82.50(2.887)$ & $51.25(2.500)$ & $16.25(2.500)$ & $\begin{array}{l}60.63 \\
(30.869) \\
\end{array}$ & $<0.001$ \\
\hline P-value & 0.019 & 0.006 & $<0.001$ & $<0.001$ & & \\
\hline \multicolumn{7}{|c|}{$\begin{array}{l}\text { PRF: Platelet-rich fibrin; BCP: biphasic calcium phosphate } \\
\text { The values are in mean (SD). }\end{array}$} \\
\hline
\end{tabular}

Table (4): percentage of Lamellar bone/osteoid of 3 groups over time periods

\begin{tabular}{|c|c|c|c|c|c|c|}
\hline \multicolumn{6}{|c|}{ Case Summaries } & \\
\hline \multicolumn{7}{|c|}{ Lamellar bone\%/osteoid } \\
\hline \multirow[t]{2}{*}{ Groups } & \multicolumn{5}{|c|}{ Healing time Period } & \multirow[b]{2}{*}{ P-Value } \\
\hline & 2 wks. & 4 wks. & 6 wks. & 12 wks. & Total & \\
\hline Control & $1.25(2.500)$ & $\begin{array}{l}8.75 \\
(4.787)\end{array}$ & $22.50(6.455)$ & $85.00(4.082)$ & 29.38 (34.345) & 0.004 \\
\hline $\mathrm{BCP}$ & $6.25(2.500)$ & $18.75(2.500)$ & $27.50(2.887)$ & $68.75(2.500)$ & $30.31(24.322)$ & $<0.001$ \\
\hline $\mathrm{BCP}+\mathrm{PRF}$ & $7.50(2.887)$ & $17.50(2.887)$ & $48.75(2.500)$ & $83.75(2.500)$ & 39.38 (30.869) & $<0.001$ \\
\hline P-value & 0.019 & 0.006 & $<0.001$ & $<0.001$ & & \\
\hline $\begin{array}{l}\text { PRF: Platel } \\
\text { The values }\end{array}$ & $\begin{array}{l}\text { fibrin; BCP: } \\
\text { mean (SD). }\end{array}$ & asic calcium $p$ & hate & & & \\
\hline
\end{tabular}

Table 5 display the comparison of woven bone between groups over healing time periods where woven bone in control group was significantly greater than in $\mathrm{BCP}$ at 4 and 12 weeks $(\mathrm{P}=$ 0.009 and $\mathrm{P}=<0.001$, respectively) and nonsignificantly at 2 and 6 weeks $(\mathrm{P}=0.075$ and $\mathrm{P}=$ 0.411 , respectively). While the woven bone in control was significantly greater than in $\mathrm{BCP}+\mathrm{PRF}$ group at 2,4 and 6 weeks $(\mathrm{P}=0.025$,
$\mathrm{P}=0.020$ and $\mathrm{P}=<0.001$, respectively) and nonsignificantly less than at 12 weeks $(\mathrm{P}=$ 1.000), in comparison between BCP and $\mathrm{BCP}+\mathrm{PRF}$ the woven bone percentage was highly significant greater in $\mathrm{BCP}$ group than $\mathrm{BCP}+\mathrm{PRF}$ group at 6 and 12 weeks that mean the maturation of bone delayed at control and $\mathrm{BCP}$ groups than $\mathrm{BCP}+\mathrm{PRF}$ group. 
Table (5): comparison of woven bone percentage between 3 groups at each time period

\begin{tabular}{|c|c|c|c|c|c|c|}
\hline \multicolumn{7}{|c|}{ Case summaries } \\
\hline \multicolumn{7}{|c|}{ Woven bone\%/osteoid } \\
\hline & & & \multicolumn{4}{|c|}{ Healing time periods } \\
\hline Group (I) & Group (J) & & 2 wks & 4 wks & 6 wks & 12 wks \\
\hline \multirow[t]{2}{*}{ Control } & BCP & $Z=I-J$ & 5.000 & 10.000 & 5.000 & 16.250 \\
\hline & & P-value & 0.075 & 0.009 & 0.411 & $<0.001$ \\
\hline \multirow[t]{2}{*}{ Control } & $\mathrm{BCP}+\mathrm{PRF}$ & $Z=I-J$ & 6.250 & 8.750 & 26.250 & -1.250 \\
\hline & & $\mathrm{P}$-value & 0.025 & 0.020 & $<0.001$ & 1.000 \\
\hline \multirow[t]{2}{*}{$\mathrm{BCP}$} & $\mathrm{BCP}+\mathrm{PRF}$ & $Z=I-J$ & 1.250 & -1.250 & 21.250 & 15.000 \\
\hline & & P-value & 1.000 & 1.000 & $<0.001$ & $<0.001$ \\
\hline
\end{tabular}

Unlike woven bone the increment of lamellar bone percentage means that the maturation of bone occurs earlier, table 6 show the lamellar bone percentage which was in control less than in BCP group (significantly at 4 and 12 weeks and nonsignificantly at 2 and 6 weeks) while lamellar in control group was significantly less than in $\mathrm{BCP}+\mathrm{PRF}$ groups at 2, 4 and 6 weeks and nonsignificantly more than at 12 weeks, moreover the percentage of lamellar bone in BCP was highly significant less than in $\mathrm{BCP}+\mathrm{PRF}$ at 6 and 12 weeks $(\mathrm{Z}=-21.250, \mathrm{P}=$ $<0.001$ and $\mathrm{Z}=-15.000, \quad \mathrm{P}=<0.001$, respectively) that mean the maturation of bone occur more and earlier at $\mathrm{BCP}+\mathrm{PRF}$ group than $\mathrm{BCP}$ and control groups.

Table (6): comparison of lamellar bone percentage between 3 groups at each time period

\begin{tabular}{|c|c|c|c|c|c|c|}
\hline \multicolumn{7}{|c|}{ Case summaries } \\
\hline \multicolumn{7}{|c|}{ Lamellar bone\%/osteoid } \\
\hline & & & \multicolumn{4}{|c|}{ Healing time periods } \\
\hline Group (I) & Group (J) & & 2 wks & 4 wks & 6 wks & 12 wks \\
\hline \multirow[t]{2}{*}{ Control } & $\mathrm{BCP}$ & $Z=I-J$ & -5.000 & -10.000 & -5.000 & -16.250 \\
\hline & & P-value & 0.075 & 0.009 & 0.411 & $<0.001$ \\
\hline \multirow[t]{2}{*}{ Control } & $\mathrm{BCP}+\mathrm{PRF}$ & $Z=I-J$ & -6.250 & -8.750 & -26.250 & 1.250 \\
\hline & & P-value & 0.025 & 0.020 & $<0.001$ & 1.000 \\
\hline \multirow[t]{2}{*}{$\mathrm{BCP}$} & $\mathrm{BCP}+\mathrm{PRF}$ & $Z=I-J$ & -1.250 & 1.250 & -21.250 & -15.000 \\
\hline & & P-value & 1.000 & 1.000 & $<0.001$ & $<0.001$ \\
\hline
\end{tabular}

\section{Osteoblast and osteoclast intensity}

Table 7 displays intensity of osteoblast and osteoclast cells at all groups over healing time periods and examined in one-sample t-test. Intensity of osteoblast cells highly significant increased over healing time in 3 groups but not observed at control and BCP groups at first 2 weeks and the highest intensity ( was observed at 12 weeks in control group, 6 weeks in BCP group and [4 and 6 weeks] in
$\mathrm{BCP}+\mathrm{PRF}$ group, that means the osteoblast cells raised early and more at $\mathrm{BCP}+\mathrm{PRF}$ group than the BCP and control groups [2.25(0.86), $1.75(1.13), 1.50(1.16)$, respectively]. Similarly, the intensity of osteoclast cells significantly increased over time periods except the control group which was not observed osteoclast cells while they were significantly more at $\mathrm{BCP}+\mathrm{PRF}$ group than $\mathrm{BCP}$ group $[\mathrm{p}=0.002, \mathrm{p}=0.041$, respectively]. 
Table (7): Intensity of osteoblast and osteoclast cells in 3 groups over time periods

\begin{tabular}{|c|c|c|c|c|c|c|}
\hline \multicolumn{7}{|c|}{ Case summaries } \\
\hline \multicolumn{7}{|c|}{ Osteoblast and osteoclast cells } \\
\hline \multirow[t]{2}{*}{ Groups } & \multicolumn{5}{|c|}{ Healing time Period } & \multirow[b]{2}{*}{ P-Value } \\
\hline & 2 wks. & 4 wks. & 6 wks. & 12 wks. & Total & \\
\hline \multicolumn{7}{|l|}{ Control } \\
\hline Osteoblast & $0.00(0.00)$ & $1.00(0.00$ & $2.00(0.00$ & $3.00(0.00$ & $1.50(1.16$ & $<0.001$ \\
\hline Osteoclast & $0.00(0.00)$ & $0.00(0.00$ & $0.00(0.00$ & $0.00(0.00$ & $0.00(0.00$ & n.a. \\
\hline \multicolumn{7}{|l|}{$\mathrm{BCP}$} \\
\hline Osteoblast & $0.00(0.00)$ & $2.00(0.00$ & $3.00(0.00$ & $2.00(0.00$ & $1.75(1.13$ & $<0.001$ \\
\hline Osteoclast & $0.00(0.00)$ & $0.00(0.00$ & $0.00(0.00$ & $1.00(0.00$ & $0.25(0.45$ & 0.041 \\
\hline \multicolumn{7}{|l|}{$\mathrm{BCP}+\mathrm{PRF}$} \\
\hline Osteoblast & $1.00(0.00)$ & $3.00(0.00$ & $3.00(0.00$ & $2.00(0.00$ & $2.25(0.86$ & $<0.001$ \\
\hline Osteoclast & $0.00(0.00)$ & $0.00(0.00$ & $1.00(0.00$ & $1.00(0.00$ & $0.50(0.52$ & 0.002 \\
\hline P-value & n.a. & n.a. & n.a. & n.a. & & \\
\hline
\end{tabular}

\section{DISCUSSION}

Reconstruction of large bone defects is challenging in oral and maxillofacial surgery. Among the great challenges facing clinical research is the development of bioactive surgical additives that enhance bone regeneration and reduce the healing time (Dohan et al., 2006) Platelet-rich fibrin (PRF) is a second- generation of autologous platelet concentrates prepared by a simple centrifugation method without adding any biochemical materials such as thrombin or calcium chloride and it is an osteoinductive biomaterial that recruit and stimulate undifferentiated mesenchymal stem cells to osteoblastic lineage and as a consequence, osteogenesis will be stimulated because the fibrin mesh contain leukocytes, growth factors, proteins and cytokines which released slowly later on (Song et al., 2018)(Öncï et al., 2016).

Biphasic calcium phosphate (BCP) is synthetic in origin, biocompatible and osteoconductive act as scaffold to support the growth of mature osteoblasts and direct apposition of bone into its surface (Abdelmagid et al., 2015). Therefore, the present study was investigated the effect of platelet rich fibrin (PRF) combined with biphasic calcium phosphate (BCP) on bone healing process in surgically created iliac bone defects of sheep.

\section{Bone formation}

In the present study the results showed highly significant more new bone formation in defects filled with $\mathrm{BCP}+\mathrm{PRF}$ than defects filled with
$\mathrm{BCP}$ and blood at each time intervals. Besides, the newly formed bone highly significant increased in all groups with healing time periods and earlier at $\mathrm{BCP}+\mathrm{PRF}$ group. These results are compatible with those of Yilmaz et al., who investigate the bone healing in a pig model between defects filled with PRF and $\beta$-TCP alone or in combination where the results revealed that the area of new bone formed was significantly greater in the defects filled with combination of PRF+ $\beta$-TCP than in defect filled with PRF and $\beta$-TCP alone (Yilmaz et al., 2014). Other histological study consisted with our results, Bölükbaşı et al., evaluate the efficacy of adding PRF to $\mathrm{BCP}$ on bone regeneration in surgically created bone defects in sheep tibia. The defects were left empty or grafted with $\mathrm{BCP}$, PRF, or BCP+PRF. Animals were sacrificed at 10,20, and 40 days. The specimens were analyzed histologically and histomorphometrically. The study revealed a histomorphometric increase in bone formation with the addition of PRF to BCP in surgically created defects in sheep tibia (Bölükbaşı et al., 2013).

Kökdere et al., demonstrate efficiency of PRF and PRF combined with autogenous graft on bone healing of rabbit tibia in different time intervals, defects were left empty or filled with autogenous bone graft alone, PRF alone and combination of PRF and autogenous bone graft. The animals were sacrificed at 30 and 60 days and the study was concluded that PRF in addition to autogenous bone graft favor the formation of new bone and keep the graft 
particles together. Moreover, PRF accelerate the bone graft healing and shorten the healing time period (Kökdere et al., 2015). These studies are also compatible with the results of Abdullah, who investigated the effect of PRF, either alone or in combination with $\beta$-TCP on bone healing in standardized rat calvarial bone defects and revealed that the addition of $\beta$-TCP to PRF significantly improved bone regeneration in the first 2 weeks after surgery and insignificant at 3,4 and 6 weeks, it was nevertheless apparent that the group receiving the combination showed better results (Abdullah, 2016,).

In vitro study Zhang et al., evaluate the effects of Choukroun's platelet-rich fibrin on bone regeneration in combination with deproteinized bovine bone mineral in maxillary sinus augmentation, 6 months after sinus augmentation found histomorphometrical percentage of newly formed bone in study group (sinus grafted with a mixture of Bio-Oss and PRF) was about 1.4 times that of the control group (sinus grafted with Bio-Oss alone) $\left(18.35 \%+5.62 \%, \quad 12.95 \%+\_\quad 5.33 \%\right.$, respectively) (Zhang et al., 2012)

\section{Bone maturation}

The results of present study revealed that the immature of newly formed bone decreased and gradually replaced by mature lamellar bone with healing time periods. This maturation of new bone in $\mathrm{BCP}+\mathrm{PRF}$ group was faster and greater than in $\mathrm{BCP}$ and control groups where the mean of mature bone at 6 weeks $(48.75,27.50,22.50$, respectively) and nearly similar at 12 weeks. These results prove that PRF is effective in the early stages of healing. The new bone in trabecular structure and mineralized observed around the graft materials, our study confirmed by Choukroun et al., evaluate the efficacy of PRF adding to freeze-dried bone allograft and compared with freeze-dried bone allograft alone used for sinus floor augmentation. Histologic examination revealed that new bone maturation in the PRF group at 4 months of healing was similar to that in the control group at 8 months (Choukroun et al., 2006).

\section{Intensity of osteoblast and osteoclast cells}

Osteoblasts, which are bone forming cells were observed in cuboidal structure on the surface of newly formed bone in all groups unevenly over healing time periods. In other words, active synthesis of osteoid matrix was shown in all groups. Our osteoblast results are compatible with those of Kökdere et al., evaluate the number of osteoblast and osteoclast over time periods at defects were left empty or filled with autogenous bone graft alone, PRF alone and combination of PRF and autogenous bone graft, the number of osteoblasts were greater in defects filled with PRF and PRF combined with autologous bone graft than defect left empty or filled with autologous graft alone (Kökdere et al., 2015).

While osteoclasts, which are bone resorbing cells present in newly formed bone surfaces that indicates the continuation of active bone forming and shaping, were observed in $\mathrm{BCP}+\mathrm{PRF}$ group greater and earlier than in $\mathrm{BCP}$ group and was not observed in control group, these osteoclast results not compatible with those of Kökdere et al., in their study the osteoclast numbers were decreased with time and greater in defects left empty and defects filled with autogenous graft than that defects filled with PRF +autogenous or PRF alone (Kökdere et al., 2015).

In the present study osteoblast cells were proliferate and increased early in $\mathrm{BCP}+\mathrm{PRF}$ group than control and $\mathrm{BCP}$ groups where the PRF containing growth factors stimulate the bone mesenchymal stem cell to differentiate into osteoblast linages. These results are similar to those of Steller et al., who demonstrates that PRF have positive effects in the therapy of bisphosphonate-related osteonecrosis of the jaw, where the negative effect of zoledronic acid on osteoblast and fibroblast proliferation and migration were especially reduced when using PRF. The use of PRF/PRP improves the behavior of zoledronic acid treated cells, but PRF appears to have an advantage in comparison to PRP (Steller et al., 2019). Other study by Li et al., concluded that PRF and insulin-like growth factor-1 can promote the osteogenic differentiation of periodontal ligament stem cells into osteoblast linages and enhance their osteogenic mineralization and regeneration of periodontal tissues (Li et al., 2018).

Similarly, Song et al., evaluate the adhesion. Proliferation and differentiation of bone marrowderived mesenchymal stem cells between fabricated 3D printed ceramic scaffolds composed of nano-biphasic calcium phosphate/polyvinyl alcohol (BCP/PVA) and (BCP/PVA/PRF) scaffolds, they found that the (BCP/PVA/PRF) scaffold promoted the cell adhesion and proliferation with stimulation of 
bone mesenchymal stem cell toward osteoblast linage more than (BCP/PVA) scaffold (Song et al., 2018).

\section{CONCLUSION}

Within the limitations of this experimental study, it can be concluded that PRF in addition to BCP increased new bone formation and maturation and decreased healing period.

\section{Recommendation}

Further researches recommended with Larger sample size using different types of bone substitute mixing with Platelet rich fibrin and evaluation of new bone formation and healing process by 3D micro $\mathrm{CT}$ scan and digital analyzing laboratory microscope.

\section{REFERENCES}

Abdelmagid, S.E., Shaaban, A.M.M., Ragaa, H., Nagui, D., 2015. Comparison between the Use of Platelet Rich Fibrin with/and Without Biphasic Calcium Phosphate for Osseointegration around Implants (Experimental Study). International Journal of Science and Research (IJSR); 6 (2): E18031807.

Abdullah, W.A., 2016. Evaluation of bone regenerative capacity in rats claverial bone defect using platelet rich fibrin with and without beta tri calcium phosphate bone graft material. Saudi Dent J; 28 (3): E109-117.

Agrawal, A.A., 2017. Evolution, current status and advances in application of platelet concentrate in periodontics and implantology. World $\mathrm{J}$ Clin Cases; 5(5): E159-171.

Bölükbaşı, N., Yeniyol, S., Tekkesin, M.S., Altunatmaz, K., 2013. The Use of PlateletRich Fibrin in Combination With Biphasic Calcium Phosphate in the Treatment of Bone Defects: A Histologic and Histomorphometric Study. Curr Ther Res Clin Exp; 75: E15-21.

Borie, E., Oliví, D.G., Orsi, I.A., Garlet, K., Weber, B., Beltrán, V., Fuentes, R., 2015. Platelet-rich fibrin application in dentistry: a literature review. Int J Clin Exp Med; 8(5): E79227929.

Chen, Y., Xu, J., Huang, Z., Yu, M., Zhang, Y., Chen, H., Ma, Z., Liao, H., Hu, J., 2017. An Innovative Approach for Enhancing Bone Defect Healing Using PLGA Scaffolds Seeded with Extracorporeal-shock-wave-treated Bone Marrow Mesenchymal Stem Cells (BMSCs). Scientific Reports; 7: E44130.
Choukroun J, Adda F, Schoeffler C, Vervelle A., 2001. An opportunity in perioimplantology 2001;42: E55-62.

Choukroun, J., Diss, A., Simonpieri, A., Girard, M.O., Schoeffler, C., Dohan, S.L., Dohan, A.J.J., Mouhyi, J., Dohan, D.M., 2006. Platelet-rich fibrin (PRF): A second-generation platelet concentrate. Part V: Histologic evaluations of PRF effects on bone allograft maturation in sinus lift. Oral Surgery, Oral Medicine, Oral Pathology, Oral Radiology, and Endodontology;101(3): E299-303.

Cortese, A., Pantaleo, G., Borri, A., Caggiano, M., Amato, M., 2016. Platelet-rich fibrin (PRF) in implant dentistry in combination with new bone regenerative technique in elderly patients. International Journal of Surgery Case Reports 28: E52.

Dohan David M., Joseph Choukroun, Antoine Diss, Steve L. Dohan, Anthony J. J. Dohan, Jaafar Mouhyi, and Bruno Gogly. 2006. Platelet-rich fibrin (PRF): A second-generation platelet concentrate.Part I: Technological concepts and evolution. Oral Surg Oral Med Oral Pathol Oral Radiol Endod;101(3): E37-44.

Dohan David M., Joseph Choukroun, Antoine Diss, Alain Simonpieri, Marie-Odile Girard, Christian Schoeffler, Steve L. Dohand, Anthony J.J. Dohane and Jaafar Mouhyi, 2006. Platelet-rich fibrin (PRF): A secondgeneration platelet concentrate. Part V: Histologic evaluations of PRF effects on bone allograft maturation in sinus lift. Oral Surgery, Oral Medicine, Oral Pathology, Oral Radiology, and Endodontology;101(3): E299303.

Jang, B.J., Byeon, Y.E., Lim, J.H., Ryu, H.H., Kim, W.H., Koyama, Y., Kikuchi, M., Kang, K.S., Kweon, O.K., 2008. Implantation of canine umbilical cord blood-derived mesenchymal stem cells mixed with beta-tricalcium phosphate enhances osteogenesis in bone defect model dogs. J Vet Sci; 9(4): E387-393.

Kim, J.-W., Shin, Y.C., Lee, J.-J., Bae, E.-B., Jeon, Y.-C., Jeong, C.-M., Yun, M.-J., Lee, S.-H., Han, D.-W., Huh, J.-B., 2017. The Effect of Reduced Graphene Oxide-Coated Biphasic Calcium Phosphate Bone Graft Material on Osteogenesis. Int J Mol Sci; 18(8): E 387-393.

Kökdere, N.N., Baykul, T., Findik, Y., 2015. The use of platelet-rich fibrin (PRF) and PRF-mixed particulated autogenous bone graft in the treatment of bone defects: An experimental and histomorphometrical study. Dent Res J (Isfahan); 12(5): E418-424. 
Kumar, P., Vinitha, B., Fathima, G., 2013. Bone grafts in dentistry. J Pharm Bioallied Sci; 5(1): E125-127.

Lee, E.-U., Kim, D.-J., Lim, H.-C., Lee, J.-S., Jung, U.-W., Choi, S.-H., 2015. Comparative evaluation of biphasic calcium phosphate and biphasic calcium phosphate collagen composite on osteoconductive potency in rabbit calvarial defect. Biomater Res; 19(1).

Li, X., Yao, J., Wu, J., Du, X., Jing, W., Liu, L., 2018. Roles of PRF and IGF-1 in promoting alveolar osteoblast growth and proliferation and molecular mechanism. Int J Clin Exp Pathol; 11(7): E3294-3301

Lucaciu, O., Gheban, D., Soriţau, O., Băciuţ, M., Câmpian, R.S., Băciuţ, G., 2015. Comparative assessment of bone regeneration by histometry and a histological scoring system / Evaluarea comparativă a regenerării osoase utilizând histometria şi un scor de vindecare histologică. Romanian Review of Laboratory Medicine; 23(1): E31-45.

Öncü, E., Bayram, B., Kantarc1, A., Gülsever, S., Alaaddinoğlu, E.-E., 2016. Positive effect of platelet rich fibrin on osseointegration. Med Oral Patol Oral Cir Bucal; 21(5): E601-607.

Rady, D., Mubarak, R., Abdel Moneim, R.A., 2018. Healing capacity of bone marrow mesenchymal stem cells versus platelet-rich fibrin in tibial bone defects of albino rats: an in vivo study. F1000Research; 7: 1573.
Song, Y., Lin, K., He, S., Wang, C., Zhang, S., Li, D., Wang, J., Cao, T., Bi, L., Pei, G., 2018. Nanobiphasic calcium phosphate/polyvinyl alcohol composites with enhanced bioactivity for bone repair via low-temperature three-dimensional printing and loading with platelet-rich fibrin. Int J Nanomedicine; 13: E505-523.

Wang, X., Li, G., Guo, J., Yang, L., Liu, Y., Sun, Q., Li, R., Yu, W., 2017. Hybrid composites of mesenchymal stem cell sheets, hydroxyapatite, and platelet-rich fibrin granules for bone regeneration in a rabbit calvarial critical-size defect model. Exp Ther Med; 13(5): E18911899.

Yilmaz, D., Dogan, N., Ozkan, A., Sencimen, M., Ora, B.E., Mutlu, I., Yilmaz, D., Dogan, N., Ozkan, A., Sencimen, M., Ora, B.E., Mutlu, I., 2014. Effect of platelet rich fibrin and beta tricalcium phosphate on bone healing. A histological study in pigs. Acta Cirurgica Brasileira; 29(1): E59-65.

Zhang, Y., Tangl, S., Huber, C.D., Lin, Y., Qiu, L., Rausch-Fan, X., 2012. Effects of Choukroun's platelet-rich fibrin on bone regeneration in combination with deproteinized bovine bone mineral in maxillary sinus augmentation: A histological and histomorphometric study. Journal of Cranio-Maxillofacial Surgery; 40(4): E321-328. 
بوخته ياشكهه وئارمانج: دووباره ئاقاكرنا كيّماسييّن ههستيـ مهزن ئيّك ز ئاستهنكِين مهزنه دبواريّ قه كولينان و

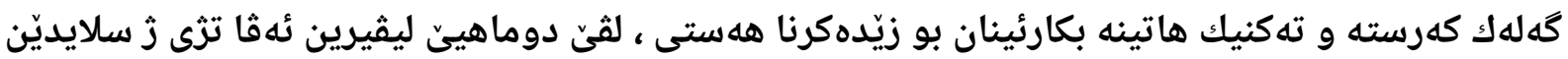

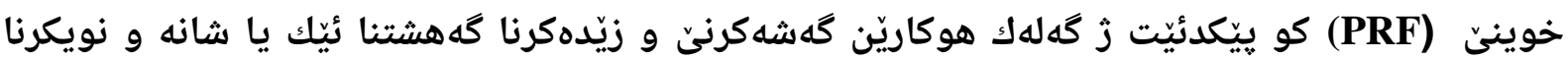
ههستى، ئهف ديراسهته بو ويّجهنديّيه كاريكهريا مادى PRF بو دوان فوسفاتى كالسيوم BCP وهك شيفا بو هلستيى خاف ل ههستيى يهزى بكارهاتيه

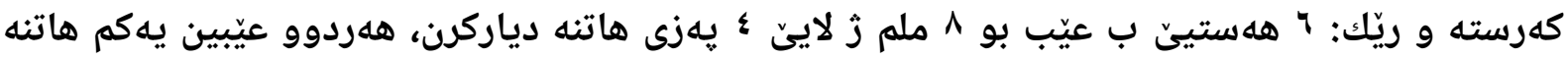

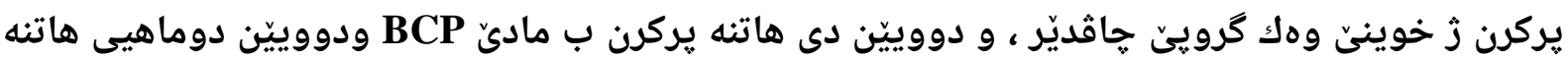
يركرن ز تيّكهلي ئل

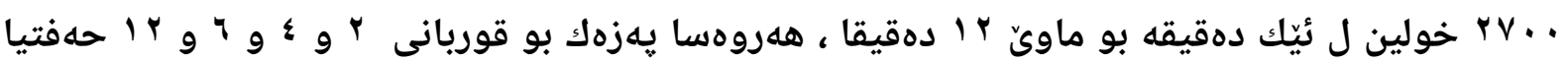

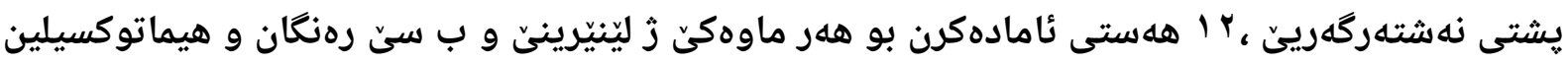

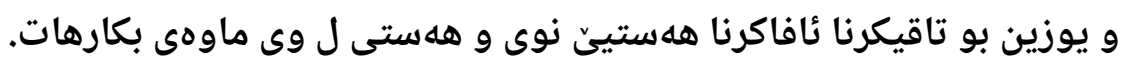

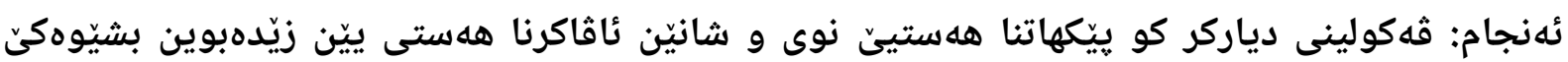

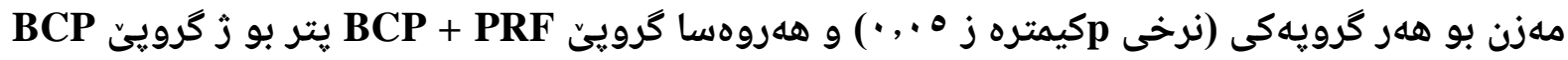

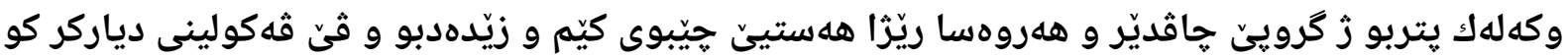

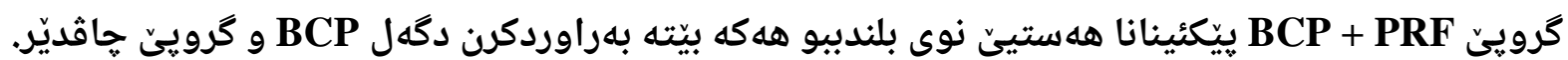
دووماهيك: لفى ثهكولينى ئهنجام دياربون كو PRF دكهل PCP دافاكرنا ههستيى نوى زيدهبيو

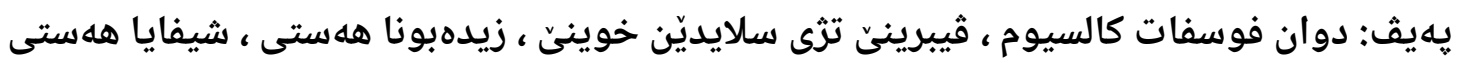

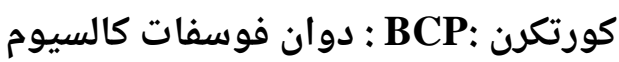
سلايديّن تزى ز خوينى و ليفين. PRF: 
الخلفية والاهداف: إعادة بناء عيوب العظم الكبيرة هي واحدة من التحديات الكبرى في مجال البحوث

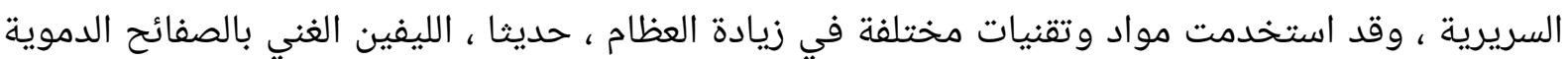

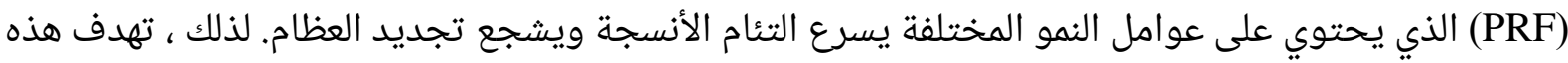

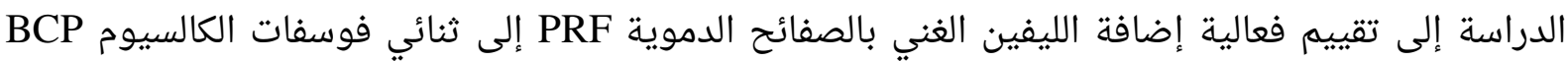
على عملية الشفاء من عيوب الحرقفي العظمي في الأغنام.

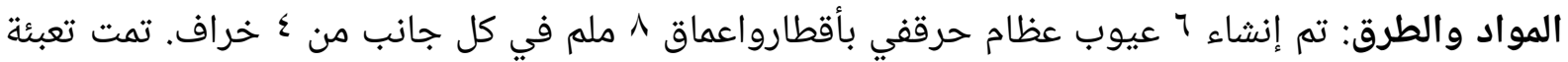

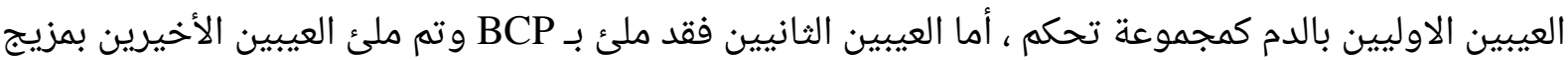
من BCP و PRF بالتساوي. الليفين الغني بالصفائح الدموية PRF اعد عن طريق الطرد المركزي من دم الأغنام

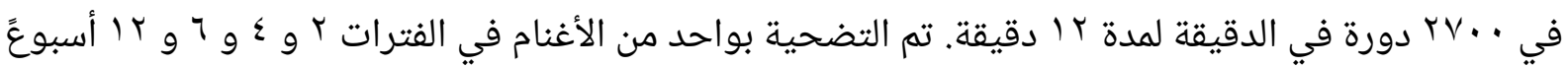

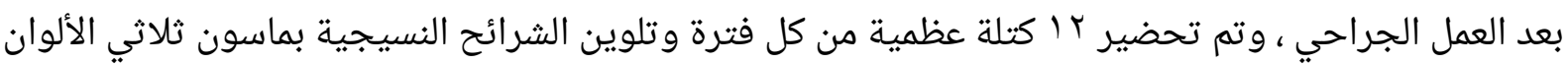
، وصبغة الهيماتوكسيلين ويوزين لفحص تكوين العظم الجديد ، نضوج العظم وكثافة خلايا المكونة والهادمة للعظم على فترات الشفاء. النتائج: أظهرت الدراسة أن نسبة تكوين العظم الجديدة وكثافة خلايا المكونة للعظم وخلايا الهادمة للعظم قد زادت بشكل كبير في كل مجموعة مع وقت الشفاء (قيمةpاقل من ه ., • ) وكانت في مجموعة BCP + PRF أعلى مما كانت عليه في المجموعة BCP وأعلى بكثيرمما كانت عليه في المجموعة التحكم في جميع الفترات

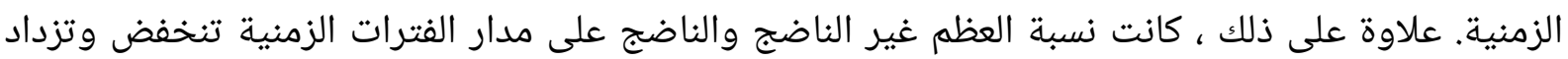

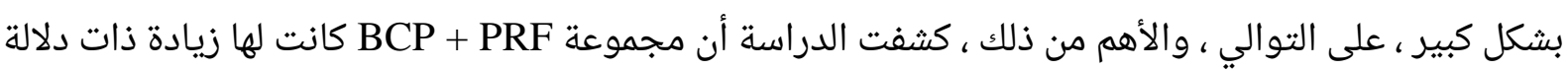
إحصائية في النسبة المئوية لتشكيل العظم الجديد وعظم ناضج ومقئ ومقارنة بـ BCP و المجموعة التحكم في جميع الفترات الزمنية. الخاتمة: في حدود هذه الدراسة التجريبية ، أظهرت نتائجنا أن إضافة PRF إلى BCP يزيد من تكوين عظم جديد. الكلمات المفتاحية: ثنائي فوسفات الكالسيوم ، الليفين الغني بالصفائح الدموية ، زيادة العظم ، شفاء العظام.

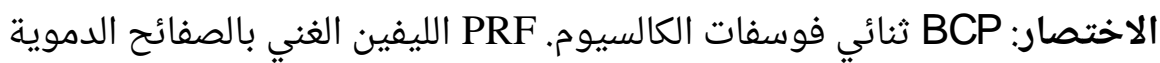

